\title{
Design of a Small Scale Pilot Biodiesel Production Plant and Determination of the Fuel Properties of Biodiesel Produced with this Plant
}

\author{
Tanzer Eryılmaz ${ }^{*}$, Muttalip Erkan $^{2}$ \\ $1^{*}$ Department of Biosystems Engineering, Faculty of Engineering-Architecture, Bozok University, 66200 Yozgat, Turkey \\ ${ }^{2}$ Department of Electric and Energy, Yozgat Vocational School, Bozok University, 66200, Yozgat, Turkey
}

\section{A R T I C LE IN F O}

\section{Article history:}

Received 14 August 2014

Accepted 03 September 2014

Available online, ISSN: 2148-127X

Keywords:

Pilot biodiesel production plant

Wild mustard seed crude oil

Refined canola oil

Oil mixture

Biodiesel

Fuel property

\begin{abstract}
A B S T R A C T
A small scale pilot biodiesel production plant that has a volume of 65 liters/day has been designed, constructed and tested. The plant was performed using oil mixture $(\mathrm{OM})(50 \%$ wild mustard seed oil $+50 \%$ refined canola oil) and methanol with sodium hydroxide $(\mathrm{NaOH})$ catalyst. The fuel properties of biodiesel indicated as density at $15^{\circ} \mathrm{C}(889.64 \mathrm{~kg}$ $\left.\mathrm{m}^{-3}\right)$, kinematic viscosity at $40^{\circ} \mathrm{C}\left(6.975 \mathrm{~mm}^{2} \mathrm{~s}^{-1}\right)$, flash point $\left(170^{\circ} \mathrm{C}\right)$, copper strip corrosion (1a), water content (499.87 $\mathrm{mg} \mathrm{kg}^{-1}$ ), and calorific value (39.555 $\mathrm{MJ} \mathrm{kg}^{-1}$ ), respectively.
\end{abstract}

${ }^{*}$ Corresponding Author:

E-mail: tanzer.eryilmaz@bozok.edu.tr

\section{Introduction}

Energy sources are classified into seven groups, such as kinetic, physical, thermal, chemical, ray, nuclear, and fission energy. In addition, energy is separated into two groups: renewable and non-renewable energy (Haktanirlar Ulutas, 2005; Aksoy et al., 2010a; Kus, 2011). A significant part of the demand for energy, which has been increasing day by day, is met through fossil based fuels around the world. In parallel with the increase in energy consumption, an increase is observed in the amount of product of combustion, leading to environmental problems (Aydogan et al., 2011). Because of the effects resulting from traditional energy sources, such as the greenhouse effects, environmental pollution, reducing dependence on traditional energy sources, and the associated environmental damage, research on the development and application of renewable energy sources has become a matter of great importance recently (Aksoy et al., 2010b).

Renewable energy sources become the need of today and biodiesel is one of them. Biodiesel, being biodegradable and non-toxic, is also essentially free of sulfur and aromatics, producing lower exhaust emissions than diesel whilst providing similar properties in terms of fuel efficiency (Ozcanli and Serin, 2011). Biodiesel can be produced from vegetable, animal and algae oil. While there are various methods for biodiesel production, transesterification is the most commonly used method (Eryilmaz and Ogut, 2011). It is known as a chemical reaction of a vegetable oil or animal fat with an alcohol, such as methanol. The reaction requires a catalyst, usually a strong base, such as sodium or potassium hydroxide, and produces new chemical compounds called methyl esters (Ozcanli et al., 2013). Biodiesel can be used in compression ignition (diesel) engines with little or no engine modifications (Oseni et al., 2013).

Biodiesel production plants are either stirred by an electric motor driving an impeller or by a recirculation pump. Production is either done by batch or continuous method (Daniyan et al., 2013).

The principal aim of present study is to design and manufacture a small scale pilot biodiesel production plant for Bozok University Engineering-Architecture Faculty Biosystems Engineering Department Biofuel Laboratory and produce biodiesel from $50 \%$ wild mustard seed crude 
oil (WMO) and $50 \%$ refined canola oil (RCO) mixture in this plant. Then, the fuel properties of biodiesel were determined and compare with EN 14214 standards.

\section{Materials and Methods} Plant

Design of a Small Scale Pilot Biodiesel Production

The biodiesel pilot plant consists of oil tank, reactor with heater and stirrer, methoxide tank with circulation pump, pure water tank with heater and stirrer, washing/conditioning tank with heater and stirrer, pure biodiesel tank, waste water tank and glycerol tank. The capacities of oil tank, reactor, methoxide tank, pure water tank, washing/conditioning tank, pure biodiesel tank, waste water tank, glycerol tank are 65 liters, 105 liters, 23 liters, 65 liters, 105 liters, 65 liters, 65 liters and 65 liters, respectively. The small scale pilot biodiesel production plant project is shown in Fig. 1.

\section{Preparing of oil mixture}

Wild mustard (Sinapis arvensis L.) seed were purchased from local market in Konya, Turkey (Fig. 2). Wild mustard seed crude oil (WMO) was obtained from the seeds produced by using a screw press with Koprulu Machine brand $2.2 \mathrm{~kW}$ electrical motors and with oilcake output of $6 \mathrm{~mm}$. Wild mustard seed was pressed at 50$55^{\circ} \mathrm{C}$ head temperature and $6.97 \%$ humidity (Fig. 3 ).

Refined canola oil was taken from a local oil plant. WMO (50\%)-RCO (50\%) oil mixture were used for biodiesel production. When mixing $\mathrm{WMO}$ and $\mathrm{RCO}$, first $50 \%$ WMO was put in, than 50\% RCO has been added. The mixture was tried to be made homogenous first with laboratory type IKA brand Yellow line OST basic model mixer at $1500 \mathrm{~min}^{-1}$, then with Yellow line brand DI 18 basic model homogenizer at $24000 \mathrm{~min}^{-1}$, for 7.5 minutes each, for a total of 15 minutes. Following this, WMO $(50 \%)$-RCO $(50 \%)$ oil mixture has been acquired (Fig. 4) (Eryilmaz, 2009).

\section{Biodiesel Production in a Small Scale Pilot Biodiesel Production Plant}

To produce biodiesel, 20 liters of oil mixture $(50 \%$ WMO-50\% RCO) was put into oil tank in a small scale pilot biodiesel production plant (Fig. 5). From this tank oil was transferred to reactor tank with helping gravity effect. In the reactor, the oil was heated up to $65^{\circ} \mathrm{C}$. Temperatures of tanks were kept stable by thermostat controlled units during reaction. 4 liters of methyl alcohol $\left(\mathrm{CH}_{3} \mathrm{OH}\right)$ which equals to $20 \%$ of the total volume of the oil mixture was used and 70 gram sodium hydroxide $(\mathrm{NaOH})$ was used as a catalyst at rate of $3.5 \mathrm{~g} \mathrm{l}^{-1}$. For reaction, methyl alcohol and sodium hydroxide were resolved in methoxide tank and methoxide was obtained. It was mixed with oil at $100 \mathrm{~min}^{-1}$ for 90 minutes. After that, mixer and heater were stopped. We waited for 60 minutes for precipitation of glycerol and glycerol was taken approximately $15 \%$. The temperature of crude biodiesel was heated up to $75^{\circ} \mathrm{C}$ and 0.5 liters of methyl alcohol was regained with the help of heat exchanger. Crude biodiesel in the reactor was transferred to washing/conditioning tank and was kept there for 10 hours so that the remaining glycerol can deposit and the end of 10 hours, glycerol was taken. During washing up, the temperature of biodiesel was $50^{\circ} \mathrm{C}$ and 4 liters of pure water at $50^{\circ} \mathrm{C}$ was used for washing as well. After washing process, we waited for 10 hours for the sedimentation of the water. Depositing water was taken to waste water tank. Drying was performed at $120^{\circ} \mathrm{C}$ under vacuum for 2 hours. Thus, biodiesel was produced from oil mixtures (50\% WMO-50\% RCO).

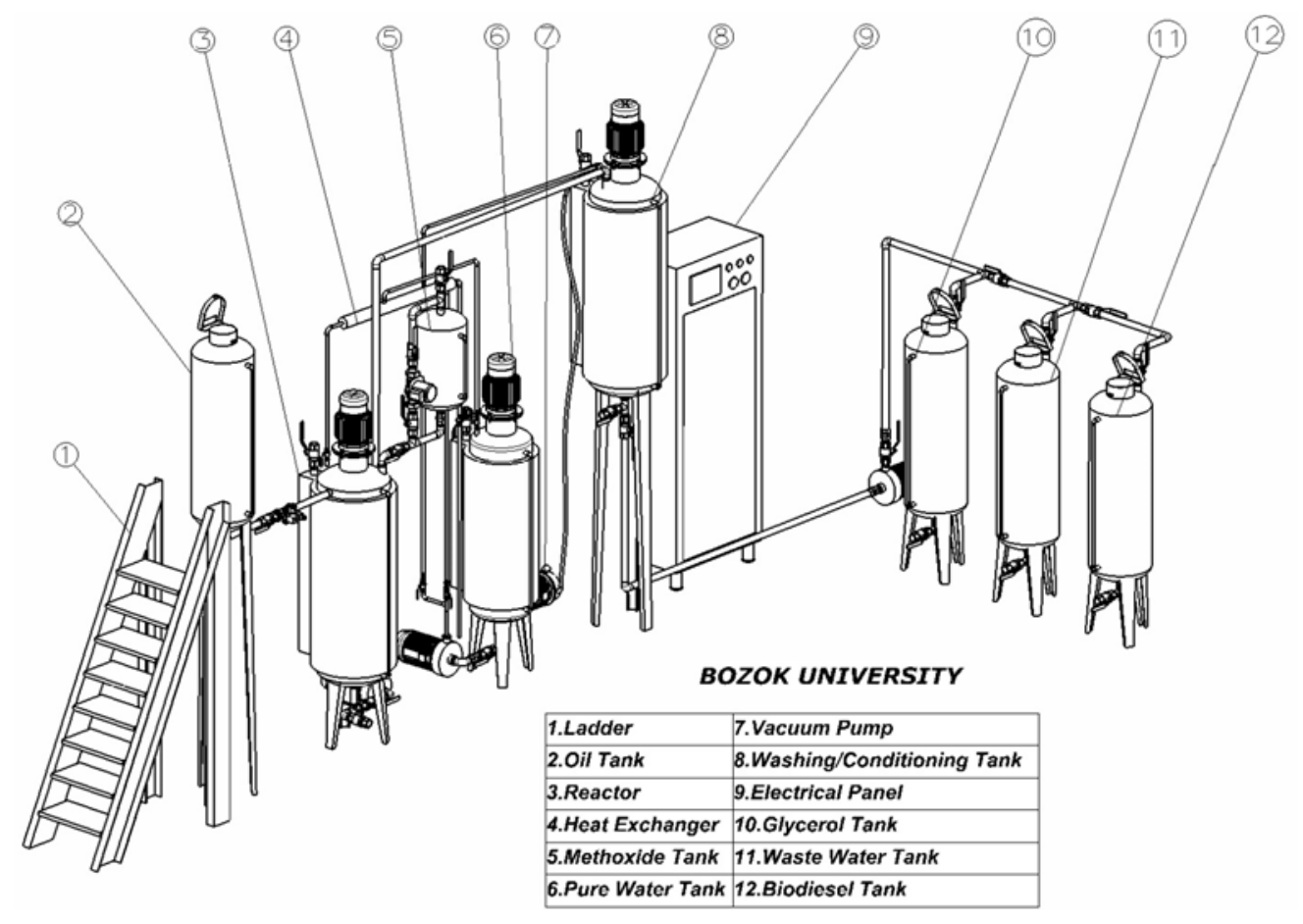

Figure $1 \mathrm{~A}$ small scale biodiesel production plant project 


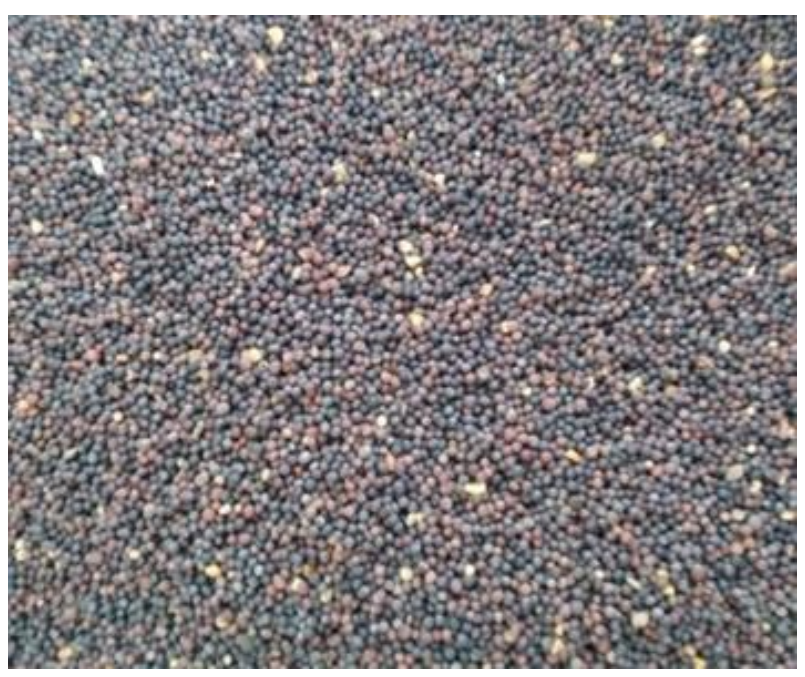

Figure 2 Wild mustard (Sinapis arvensis L.) seeds

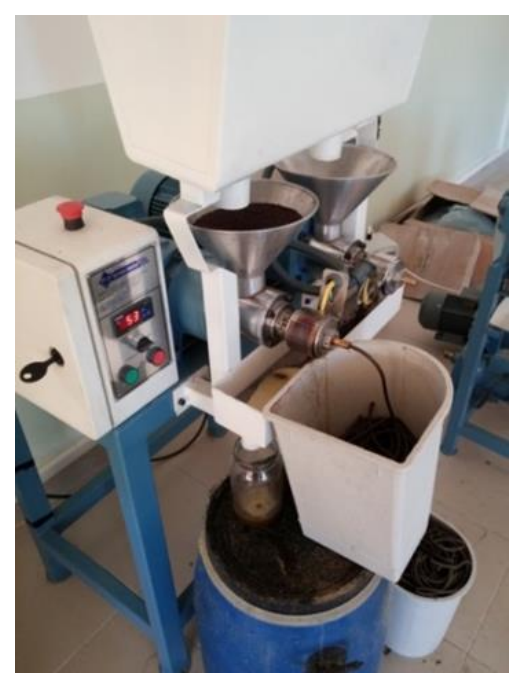

Figure 3 A screw press

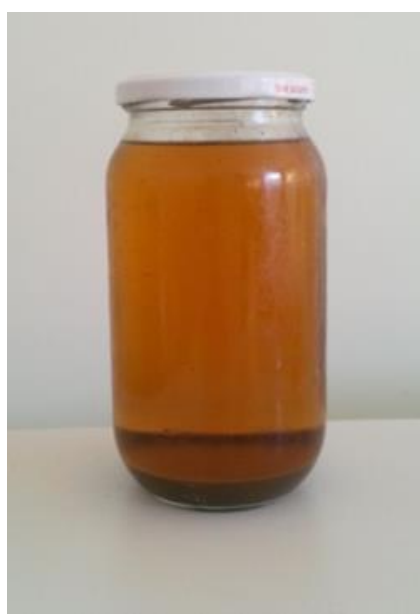

a

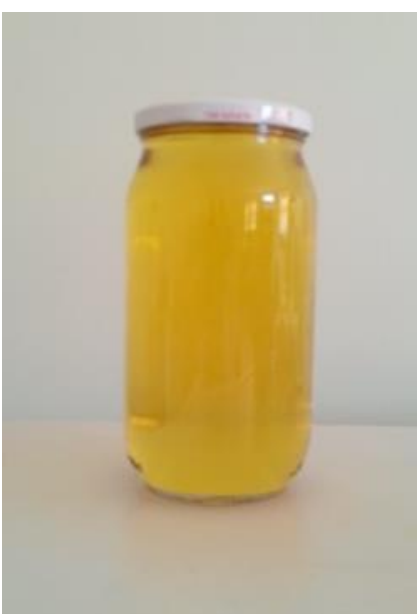

b

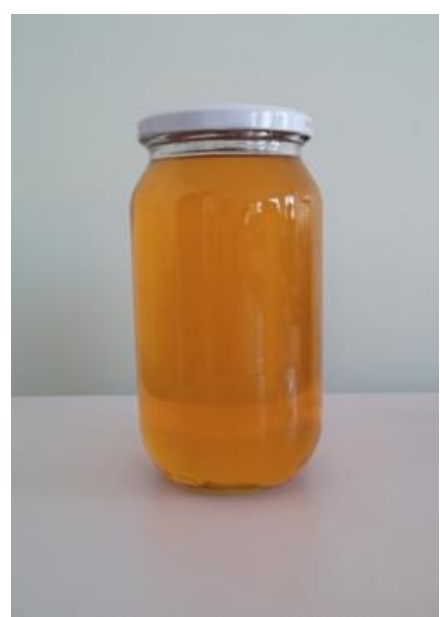

$\mathrm{c}$

Figure 4 a)Wild mustard seed oil (WMO) b)Refined canola oil (RCO) c)Oil mixture (OM) (50\%WMO+50\%RCO)

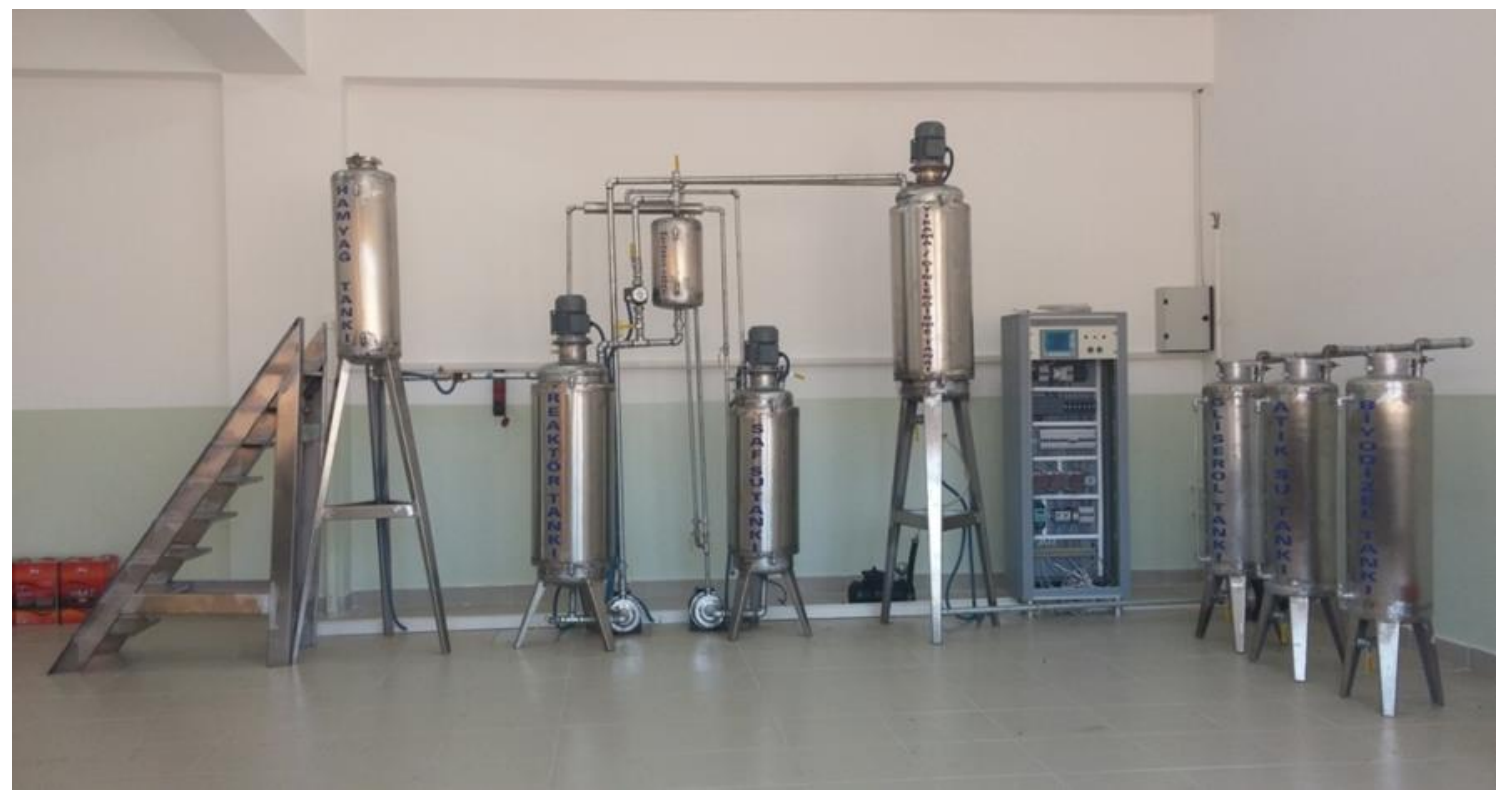

Figure 5 A small scale pilot biodiesel production plant 


\section{Results and Discussion}

In this study which was carried out using wild mustard (Sinapis arvensis L.) seed, $25.5 \%$ of oil was obtained from a screw press. The moisture content of seeds was measured as $6.97 \%$. $6 \mathrm{~mm}$ of oil cake output was used and the calorific value of wild mustard seed oil cake was measured as $22.909 \mathrm{MJ} \mathrm{kg}^{-1}$. After that, WMO and RCO were mixed and used for biodiesel production. The fuel properties of oil mixture, B100 and of the diesel used as reference were given in Table 1.

As a result of the analysis of the oil mixture, its density was found to be $917.86 \mathrm{~kg} \mathrm{~m}^{-3}$, flash point was $219^{\circ} \mathrm{C}$, copper strip corrosion was $1 \mathrm{a}$, water content was $357.90 \mathrm{mg} \mathrm{kg}^{-1}$, heating value was $39.924 \mathrm{MJ} \mathrm{kg}^{-1}$, and kinematic viscosity was $39.631 \mathrm{~mm}^{2} \mathrm{~s}^{-1}$, respectively. As a result of the analysis of the biodiesel from oil mixture, its density was found to be $889.64 \mathrm{~kg} \mathrm{~m}^{-3}$, flash point was $170^{\circ} \mathrm{C}$, copper strip corrosion was $1 \mathrm{a}$, water content was $499.87 \mathrm{mg} \mathrm{kg}^{-1}$, heating value was $39.555 \mathrm{MJ} \mathrm{kg}^{-1}$, and kinematic viscosity was $6.975 \mathrm{~mm}^{2} \mathrm{~s}^{-1}$, respectively. As can be seen in the results only kinematic viscosity is higher than EN 14214 standard and the other fuel $\begin{array}{lllll}\text { properties of oil mixture }(50 \% & \mathrm{WMO}+50 \% & \mathrm{RCO})\end{array}$ biodiesel is within the limiting values specified in EN 14214.

\section{Acknowledgments}

This study was supported by the Scientific Research Projects Foundation of Bozok University (Project no. 2013MMF/A53).

Table 1 Fuel properties of diesel, B100 and oil mixture

\begin{tabular}{l|ccccc}
\hline Property & Unit & OM & B100 & EN 14214 & Diesel \\
\hline Density at $15^{\circ} \mathrm{C}$ & $\mathrm{kg} \mathrm{m}^{-3}$ & 917.86 & 889.64 & $860-900$ & 823.41 \\
Kinematic viscosity at $40^{\circ} \mathrm{C}$ & $\mathrm{mm}^{2} \mathrm{~s}^{-1}$ & 39.631 & 6.975 & $3.5-5.0$ & 2.641 \\
Flash point & ${ }^{\circ} \mathrm{C}$ & 219 & 170 & $>101$ & 59 \\
Water content & $\mathrm{mg} \mathrm{kg}^{-1}$ & 357.90 & 499.87 & $<500$ & 36.757 \\
Copper strip corrosion $\left(3 \mathrm{~h}\right.$ at $\left.50^{\circ} \mathrm{C}\right)$ & - & $1 \mathrm{a}$ & $1 \mathrm{a}$ & 1 & $1 \mathrm{a}$ \\
Calorific Value & $\mathrm{MJ} \mathrm{kg}^{-1}$ & 39.924 & 39.555 & $>35^{*}$ & 45.082 \\
\hline
\end{tabular}

\section{References}

Aksoy F, Baydir SA, Bayrakceken H. 2010a. The Viscosity at Different Temperatures of Soybean and Sunflower Biodiesels and Diesel Fuel Blends. Energy Sources, Part A, 32: 148-156.

Aksoy F, Baydir SA, Bayrakceken H. 2010b. An Investigation on the Effect in the Viscosity of Canola and Corn Oil Biodiesels at a Temperature Range of 0 to $100^{\circ} \mathrm{C}$. Energy Sources, Part A, 32: 157-164.

Aydogan H, Ozcelik AE, Acaroglu M. 2011. The Effect of Peanut Oil Methyl Ester on the Performance and Emissions of a Diesel Engine with a Pump Injection Fuel System. Energy Education Science and Technology Part A: Energy Science and Research, 28: 189-200.

Daniyan IA, Adeodu AO, Dada OM, Aribidara AA. 2013. Design of a Small Scale Biodiesel Processor. Journal of Emerging Trends in Engineering and Applied Sciences (JETEAS), 4: 576-580.

Eryilmaz T. 2009. The Effect of the Different Mustard Oil Biodiesel Blending Ratios on Diesel Engines Performance, Selcuk University, Natural and Applied Science, Agricultural Machinery, PhD Thesis, Konya, Turkey.
Eryilmaz T, Ogut H. 2011. The Effect of the Different Mustard Oil Biodiesel Blending Ratios on Diesel Engines Performance. Energy Education Science and Technology Part A: Energy Science and Research, 28: 169-180.

Haktanirlar Ulutas B. 2005. Determination of the Appropriate Energy Policy for Turkey. Energy, 30: 1146-1161.

Kus R. 2011. The Effect of Raw Corn Oil and Diesel Fuel Mixture on Engine Performances and Emissions. Energy Education Science and Technology Part A: Energy Science and Research, 28: 469-474.

Oseni MI, Tuleun LT, Musa A. 2013. Development and Performance Evaluation of a Small Scale Biodiesel Production Pilot Plant. Journal of Emerging Trends in Engineering and Applied Sciences (JETEAS), 4: 679-685.

Ozcanli M, Serin H. 2011. Evaluation of Soybean/Canola/Palm Biodiesel Mixture as an Alternative Diesel Fuel. Journal of Scientific and Industrial Research, 70: 466-470.

Ozcanli M, Gungor C, Aydin K. 2013. Biodiesel Fuel Specifications: A Review. Energy Sources, Part A, 35: 635647. 